\title{
$[1]$
}

\section{The Symbolic Vocabulary of Public Executions}

\author{
Anton Blok
}

One of the most dramatic changes in the history of European legal systems has been the transition from public executions to imprisonment, which took place at the end of the eighteenth century and the beginning of the nineteenth. Although this development has often been discussed (e.g., Foucault 1977) and much has been written on public executions in general, especially with regard to the German territories (e.g., Schild 1980; Dülmen 1984), one would like to know more about the meaning of these forms of punishment, and the reasons that they met with increasing resistance until they finally became intolerable. The sentences given well over 500 members of the robber bands in the Lower Meuse-the so-called Bokkerijders-between 1741 and 1778 may be of interest because they show a development that foreshadows the main transition from corporal punishment in public to confinement in workhouses and prisons. My sources are chiefly court records, which I have supplemented with the correspondence and published writings of contemporary judges, government officials, priests, and other notables. Seeking to decode the messages inscribed in the cultural forms of theatrical punishments, this chapter draws heavily on material I have collected for a forthcoming monograph on the social history of these robber bands. ${ }^{1}$

${ }^{1}$ Most of the archival sources I used are located in the Rijksarchief of Limburg in Maestricht, section “Landen van Overmaas, criminal procedures, 1741-1778." For more precise references, see Blok 1979, 1981 . 


\section{The Area}

The robber bands operated on the east bank of the Meuse, in the rural districts enclosed by the towns of Maestricht, Aix-la-Chapelle, Gulick, and Roermond. Up to the early eighteenth century, this part of the Lower Meuse had suffered from frequent military operations. The rural population had to feed and lodge armies in transit and in winter camps if there was no chance to pay the military off through expensive sauvegardes. Worse still was the scourge of disbanded soldiers who indulged in looting and plundering villages and farms (see Wouters 1970; Gutmann 1980). Although virtually without protection (except flight), the inhabitants of this frontier area of the Dutch Republic and the Spanish (after 1713, Austrian) Netherlands succeeded in recovering from these afflictions. Between 1650 and 1750, the rural population remained fairly stable in this hilly, wooded, and relatively fertile region of mixed farming where large tenant farms dominated. As elsewhere in Europe, it was only after 1750 that the population of the Lower Meuse started to grow rapidly. Contemporary maps indicate a relatively dense population (about fifty inhabitants per square kilometer) grouped into many small, nucleated villages and towns. Most settlements fell into the pattern of what are customarily called "street villages"; of these, many had originated as Waldhufendörfer; place names ending in -rode, -rade, -rath, -hage, -heide, -veld, and so on, reveal the late-medieval foundation of these settlements as forest- and heath-clearing villages. Access to land was all-important. Broadly speaking, there were two main social classes, each defined in relation to control over land. Exclusion from ownership of land implied social exclusion too (see Slicher van Bath 1963; Roebroeck 1967; Philips 1975; Schrijnemakers 1984).

There were also several industries in the area, not only in the towns but also in the rural villages, which produced textiles, metal, and leatherwork. The entire region, in fact, formed an offshoot of the important industrial concentration around Liège. Apart from agriculture, therefore, people lived off several rural domestic manufacturers and commerce. We know, for example, of an ironworkers guild (gilde van den eyseren) in the district of Geleen that incorporated makers of locks, hinges, chains, harnesses, and scissors. In 1720 the guild numbered 109 members from several towns and villages in one of the Austrian enclaves in the Lower Meuse. Because of falling prices, the guild formed a cartel to fix prices and production quotas. Work stopped during the summer months to allow guild members to find employment in harvest work. 


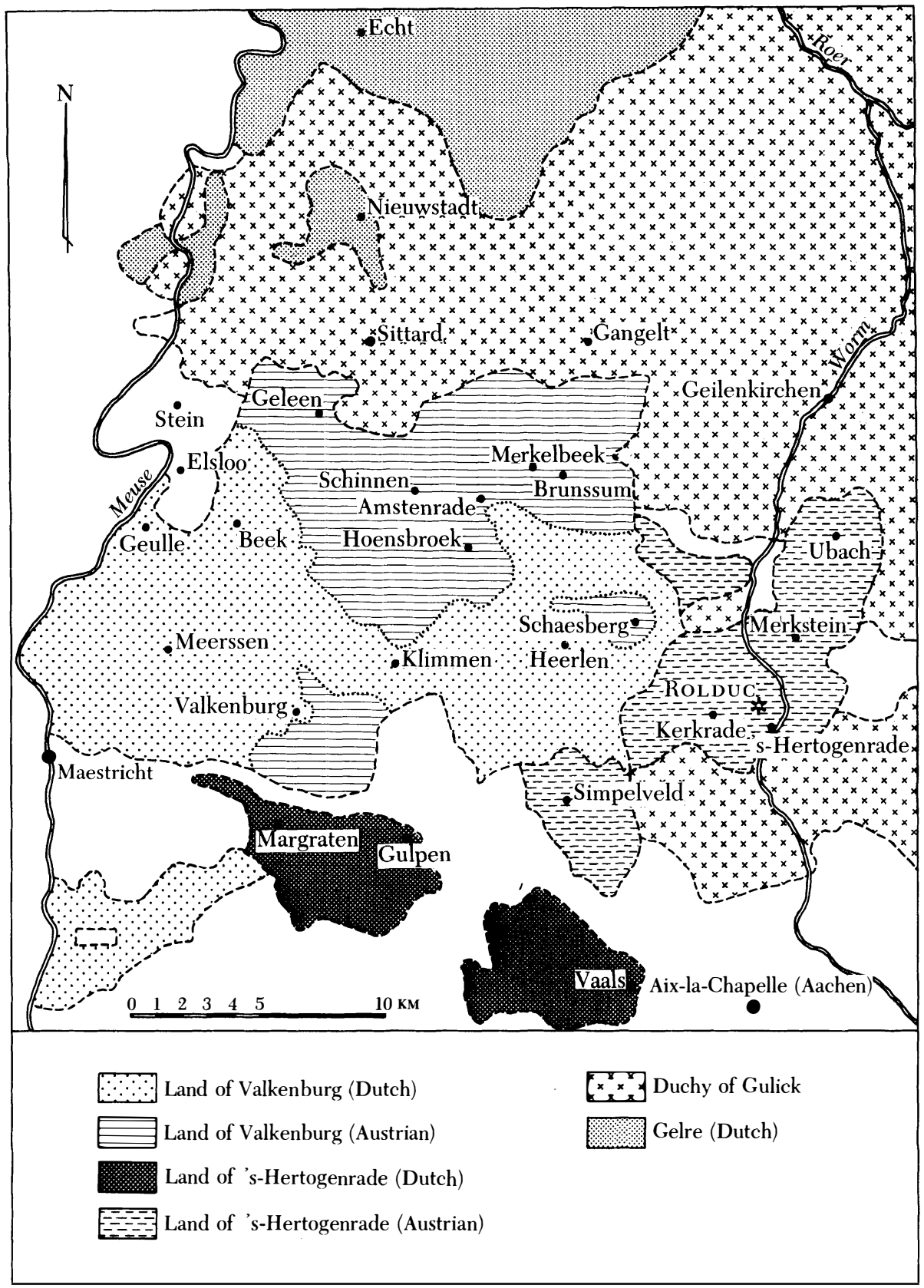

Map 1. Political fragmentation of the eastern Meuse Valley, 1715-1785 
The cartel expanded to include ironworkers from other places in the area. By 1740 its membership had grown to 280 ironworkers (Thurlings and van Drunen 1960).

At the time this part of the Meuse valley was politically fragmented to a considerable extent (see Map 1). Including parts and enclaves of Dutch and Austrian territories, together with sections of the duchy of Gulick and various autonomous and semiautonomous seigneuries, it was in several respects a border area par excellence. Apart from the political frontiers, there were many different jurisdictions, and the boundary line dividing Protestants from Roman Catholics ran right across the area. The transitional character of the entire region was reinforced by its location on commercial and military crossroads. The Lower Meuse formed a bridgehead in a major European interaction zone-connecting Flanders with the Rhineland, and the Dutch Republic with the southern Netherlands and France. Finally, we should note the extremely peripheral location of the Dutch and Austrian territories with respect to their political centers-The Hague and Brussels. Disconnected from the other parts of the Dutch Republic and the Austrian Netherlands, respectively, these territories were true enclaves (Wouters 1970; Haas 1978).

\section{The Bokkerijders: Background and Operations}

Over a period of almost fifty years-from the late 1720s through the early 1770 s - various bands of changing size and composition carried out more than one hundred attacks on inns, shops, breweries, and various Roman Catholic churches, rectories, wayside chapels, and in particular tenant farms. All the attacks took place in the area of the Lower Meuse. The size of the bands ranged from a dozen to well over 150 participants. The raids fell into three distinct periods, each of which came to an end with mass arrests, trials, and executions. The first phase, which lasted until the early 1740s, saw more than sixty operations, most of which were directed against churches, while at least ten raids involved massive attacks on farms and rectories. The second phase, which covered only the years 1749-50, included just two outings and was to some extent a short-lived revival of what had remained of the earlier bands. In the third phase, from the early 1750s onward, the ranks of the robbers swelled considerably. Various local bands participated in several largescale attacks against at least a dozen farms, two rectories, one hermitage, one monastery, and one church. As in the early 1740s, a haphazard 
outing not authorized by the leaders and carried out toward the end of 1770 led to the discovery and subsequent demise of the robber bands.

In the early stages of the Bokkerijder movement-if that is an adequate description of these sustained forms of brigandage-most of the robbers came from the easternmost enclaves of the Austrian Netherlands and the adjoining reaches of the duchy of Gulick. With the towns of Nieuwstadt and Heerlen, the Dutch territories were only modestly represented at that time. Later, large groups of people from neighboring Dutch districts joined in the raids, while certain Austrian territories and the land of Gulick stopped being important areas of recruitment. All attacks took place late in the evening or in the early morning. During these nightly ventures the robbers looked for money, jewelry, clothing, food, and other valuable goods. Victims were often maltreated (to make them talk first and to keep them quiet after), and a few of them lost their lives. But not all operations involved the same amount of violence, nor were they all equally successful. Several important outings failed-some because the victims or their neighbors managed to give the alarm; others because the robbers found only items of little value. And it is significant that on a number of occasions, most notably during the large-scale operations in 1770 , the victims were conspicuously spared, if they woke up at all.

How many people actually participated in the operations of the robber bands we cannot possibly know. What we do know is that about 600 people were tried for being members of the "notorious band." In the early 1740 s, about 170 people (including well over 20 women) appeared before local courts. About ten years later, 29 people were tried, including 5 men who had also been active in the first period. During the trials of the 1770 s, close to 400 people ( 6 of them women) were convicted (see Table 1.1), so I could trace more than 500 verdicts-which were all

Table 1.1. Number of Bokkerijders Brought to Trial, 1741-1778

\begin{tabular}{lccrr}
\hline \multicolumn{1}{c}{ Outcome of Trial } & $\begin{array}{c}\text { 1st } \\
\text { Phase }\end{array}$ & $\begin{array}{c}\text { 2nd } \\
\text { Phase }\end{array}$ & $\begin{array}{c}\text { 3rd } \\
\text { Phase }\end{array}$ & Total \\
\hline Tried and sentenced & 113 & 27 & 371 & 511 \\
Tried but sentence unknown & 54 & 2 & 28 & 84 \\
Unknown* & 50 & 6 & 3 & 59 \\
$\quad$ Total & 217 & $35^{* *}$ & 402 & 654 \\
\hline
\end{tabular}

*All these people were mentioned as accomplices in the records. If they were tried, the trial records did not survive.

**Five of these people had also been active in the first period, which brings the total down from 654 to 649 , including 36 women ( 30 of whom were active in the first period). 
carried out. Most of these convictions involved death sentences. No less than 354 Bokkerijders were put to death one way or another (see Table 1.2). In most cases these executions took place near the robbers' home towns. Relatively few convicted robbers -12 after being flogged, and 2 after being flogged and branded-were banished (they were mostly women and young men). For lack of sufficient proof, 17 suspects were released from detention. Only 3 people were sent to houses of correction. As many as 46 died in prison; in most cases we know the circumstances under which they expired, partly because they can be read from the sentences that the local courts passed on their remains. Finally, because many suspects had fled before the trials got under way, at least 76 people were tried in absentia. (The actual number was probably over 100; we know of an additional 34 fugitives under trial for whom no sentences could be traced.) Most of the fugitives were banished, and we know that at least 11 of them were hanged in effigy (Table 1.2). In order to understand the particulars of all these sentences, we have to know

Table 1.2. Outcome of Trials against Bokkerijders, 1741-1778

\begin{tabular}{lrrrr}
\hline \multicolumn{1}{c}{ Sentence/Outcome } & $\begin{array}{c}\text { lst } \\
\text { Phase }\end{array}$ & $\begin{array}{c}\text { 2nd } \\
\text { Phase }\end{array}$ & $\begin{array}{c}\text { 3rd } \\
\text { Phase }\end{array}$ & Total \\
\hline $\begin{array}{l}\text { Death sentence not specified, but } \\
\text { presumably gallows }\end{array}$ & 4 & - & 45 & 49 \\
Gallows & 45 & 16 & 191 & 252 \\
Gallows and additional punishments & 1 & 1 & 1 & 3 \\
Broken on the wheel & - & 1 & 4 & 5 \\
Broken on the wheel and additional & 5 & - & 1 & 6 \\
$\quad$ punishments & - & - & 2 & 2 \\
Garroted & 27 & - & - & 27 \\
Garroted and additional punishments & 6 & - & - & 6 \\
Decapitated & 4 & - & - & 4 \\
Decapitated and additional punishments & 11 & 4 & 31 & 46 \\
Died in detention & 3 & - & 11 & 14 \\
Banishments & 1 & - & 64 & 65 \\
Convicted in absentia: banishment & 1 & 5 & 5 & 11 \\
Convicted in absentia: hanged in effigy & - & - & 3 & 3 \\
Confinement & 5 & - & 12 & 17 \\
Released from detention & 1 & - & 1 & 2 \\
Warrant for arrest refused & 114 & 27 & 371 & $512^{*}$ \\
$\quad$ Total & & & & \\
\hline
\end{tabular}

*These 512 sentences (verdicts) concern 511 persons because one person was tried and convicted two times: a woman from the first period was first banished after being flogged and branded, then later sent to the gallows and hanged. 
what these people were punished for and what might have brought them to take the road of brigandage.

The collective biography of the Bokkerijders, which I compiled from the surviving court records and a few contemporary publications, reveals that these robbers were not bandits-that is, "outlaws"-in the strict sense of the word. On the contrary, virtually all of them led ordinary lives in their home towns. Most of the Bokkerijders were married and had children and a fixed residence. In fact, many were born and bred in the same area in which they carried out their raids- the east bank of the Lower Meuse. Some of the robbers even lived in the same village as their victims, and a few of them were close neighbors of the victims. This familiarity with victims and targets may explain the various forms of disguise that the robbers adopted. As mentioned before, they operated by night (hence one of their nicknames, nachtdieven-literally, night thieves). We know that the women used to dress as men, while the men often wore military attire and, to further hide their identity, made use of military idiom. Others blackened their faces and put on visors, wigs, false beards, caps, and other outlandish headgear. It should not surprise us, then, that the robbers fled when seen or caught in the very act of stealing. As local people, they had good reason to fear recognition. Thus, the Bokkerijders were far from being outlaws, vagrants, roaming beggars, or disbanded soldiers, although several had belonged to some of these categories at one time or another. Yet their military disguise as well as their relationship with an itinerant or peripatetic way of life are of fundamental importance for understanding the history of these bands.

Looking at the occupational background of the Bokkerijders, which I could trace for two-thirds of them, one finds artisans and retail merchants (peddlers, carters) strongly represented. Together they made up about 60 percent of the participants in all three stages of band operations, while farmers and day laborers accounted for scarcely 20 percent. For a distinctly rural area, people of agrarian background were notably underrepresented in the bands (see Table 1.3). Among the artisans, the skinners especially loomed large, most notably in the first phase. In fact, the first robber bands coalesced around a widely extended network of skinners-people whose job it was to kill sick animals, to dispose of dead cattle, to flay horses, and to remove other offal and remains. Skinners also assisted the executioner; they did the dirty work, such as dragging dead bodies of convicts from the prison to the gallows, where they had to hang them in chains or bury their remains. 
Table 1.3. Occupational Background of Bokkerijders

\begin{tabular}{|c|c|c|c|c|}
\hline & $\begin{array}{c}\text { lst } \\
\text { Phase }\end{array}$ & $\begin{array}{l}\text { 2nd } \\
\text { Phase }\end{array}$ & $\begin{array}{c}\text { 3rd } \\
\text { Phase }\end{array}$ & Total \\
\hline Artisans & 61 & 14 & 135 & 210 \\
\hline Skinners & 17 & - & 5 & 22 \\
\hline Ironworkers & 17 & 4 & 18 & 39 \\
\hline Shoemakers & 5 & 7 & 20 & 32 \\
\hline Saddlers & 1 & - & 6 & 7 \\
\hline Spinners and weavers & 14 & 2 & 44 & 60 \\
\hline Others & 7 & 1 & 42 & 50 \\
\hline Commerce/transport & 21 & 4 & 31 & 56 \\
\hline Agriculture & 10 & 5 & 70 & 85 \\
\hline Day laborers & 8 & 3 & 50 & 61 \\
\hline Farmers & 2 & 2 & 20 & 24 \\
\hline Authorities & 3 & 3 & 11 & 17 \\
\hline Miscellaneous & 27 & 2 & 30 & 59 \\
\hline Innkeepers & 5 & - & 10 & 15 \\
\hline Entertainers & 6 & - & 3 & 9 \\
\hline Miners & 6 & - & 2 & 8 \\
\hline Beggars & 4 & 1 & 4 & 9 \\
\hline Soldiers* & 6 & 1 & 5 & 12 \\
\hline Others & - & - & 6 & 6 \\
\hline Total & 122 & 28 & 277 & 427 \\
\hline
\end{tabular}

Note: Occupational background is available for only two-thirds of the Bokkerijders.

*An additional dozen of the robbers for whom we know occupations also had military experience.

Together with some of their womenfolk, skinners from a dozen different villages and towns in the eastern Meuse valley (see Figure 1.1), were the main protagonists in the church robberies that were carried out in the early 1730s in at least twenty-five different locations. But the skinners also had an important part in the preparation and organization of the other raids in the first phase, while the division of the booty and sale of stolen goods (through Jewish receivers in the larger towns) was often in their hands.

The network of skinners was distinctly regional and endogamous. Like elsewhere, the endogamy of the skinners in the Lower Meuse resulted from the low value that the society put on their work (Wilbertz 1979; Blok 1981a, 1981b). Charged with the disposal of carrion and other refuse, their profession brought them into contact with dirt, with "matter out of place." Hence they were stigmatized and placed at the margin of established society, which explains their low chances of marrying outside their occupational group. Nor could they easily enter into other occupations or crafts. Having their business at the edge of the village or 

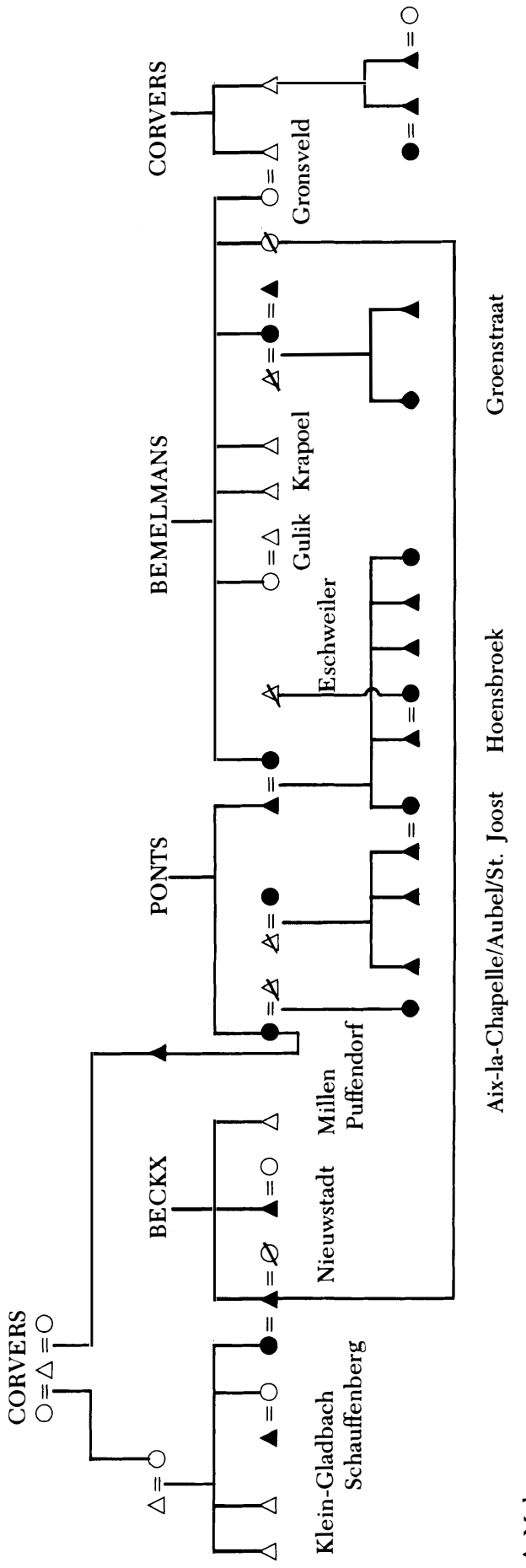

ป⿱一兀) 
in small rural hamlets near the larger settlements, the skinners were also marginal in a more literal sense-they were geographically and physically separated from the community they served. Because one family of skinners could provide for an entire rural community, the isolated positions of these craftsmen generated a far-flung, interlocal network of kin relations covering a large part of the eastern Meuse valley (see Figure 1.1 and Map 1).

The skinners shared their low social status, peripheral location, and tactical mobility with other occupational groups that were strongly represented in the bands. We hear of peddlers, part-time beggars, musicians, jugglers, carters, innkeepers, and shoemakers. Although all these people had a fixed residence (and thus certainly did not belong to the fahrende Leute, or itinerant people), many of them moved a great deal between the villages and towns, while some formed main junctions of social networks. It is among these linkmen, especially the skinners, innkeepers, and shoemakers, that we find the most important leaders of the bands.

Apart from these more or less itinerant folk (to whom also belonged the mostly poor spinners and weavers, who became more prominent in the later stages of the Bokkerijders' exploits), the skinners maintained relations with people involved in leatherwork, such as the saddlers, shoemakers, and cobblers, whose number rose sharply during the last phase of the bands. The robber bands were thus tied together by occupational links, ties of sociability, linkages of kinship and marriage (certainly not restricted to the group of the skinners), and local bonds. Quite often these various types of relations were intertwined, adding to the social cohesion of the Bokkerijders, who were settled along the frontiers of this politically fragmented area. They lived in the smaller neighborhoods near larger places, or on the outskirts of villages and towns.

Thus, the Bokkerijders were "ordinary" citizens and at best part-time robbers. They had a permanent residence, which in itself gave them civil rights denied to all fahrende Leute. One should therefore distinguish them from outlaws and vagrants, who could be arrested and tried straightaway simply because they lacked a domicile. One bailiff stated his predicament in the summer of 1743: "Although apparently free and respectable citizens, these robbers are even worse and more dangerous than the foreign vagabonds, vagrants, and thieves, against whom the placards and edicts have provided sanctions." Indeed, the accumulation of evidence required for the arrests slowed court proceedings to a considerable extent, which enabled many suspects to leave the area. As 
already noted, well over one hundred of the robbers were tried in absentia.

Many Bokkerijders occupied marginal positions and were highly mobile. Both tactical mobility and peripheral location made them less subject to tight forms of social control. These conditions held particularly true for the skinners, who could therefore organize themselves over considerable distances. Together with representatives from other marginal and mobile occupations, the skinners were more effective than the judicial authorities, who were bound to small districts, so in a way the regional, endogamous network of the skinners provided the infrastructure of these bands, while, as we shall see, the skinners also set the tone for the ideological orientation of the robbers.

No less important for understanding the composition and organization of the robber bands were other implications of the skinning trade. Their visits to farms at unusual times enabled them to acquire an intimate knowledge of the area in which they worked. Their sense of place must have been formidable, for they could find their way in a large area in the middle of the night, going to the rendezvous and target and returning before dawn, every step of which required coordinated timing. Even more than the peddlers, carters, entertainers, and other itinerant folk, skinners had an excuse to hang around at unlikely times and places. As emergency butchers, their presence at an uncommon location at an unusual time did not raise suspicion, and neither did their carrying of heavy packs and bundles. Moreover, the skinning trade required considerable physical strength and adroitness with knives. The skinners did not hesitate to use the same tortures on their victims that hangman's assistants used, such as burning people with hot sulfur or boiling oil and threatening to cut them up.

Other occupations prevalent among the robbers had similar implications for their means of organization and orientation. For example, the shops and workplaces of shoemakers and cobblers must have become meeting places similar to inns and taverns (Hobsbawm and Scott 1980). In fact, we know that at least four shoemakers and six innkeepers were prominent as leaders in all three phases of the Bokkerijder movement. Together with the skinners who assumed positions of leadership in the bands, these shoemakers and innkeepers also had an important part in both the recruitment and the organization of the bands. It seems that spinners and weavers too moved around a lot, and hence were much like some of the peddlers and carters, going back and forth between town and countryside. Similar patterns of mobility could be ascertained for 
the cobblers, who often had to visit scattered farms and hamlets to carry out their craft.

Yet the social and spatial organization of the skinners and their allies cannot explain why these people organized themselves into robber bands and attacked and broke into churches and farms, maiming and sometimes killing the inhabitants. The organizational aspects tell us only how the robbers operated and suggest their power chances vis-à-vis other localized groups, such as the farmers and especially the authorities, who were tied to jurisdictions of limited size in an area characterized by extreme political fragmentation. The implications of the crafts and trades prominent in the bands certainly did not determine the operations of the robbers. On the other hand, we cannot understand the actions of the Bokkerijders without taking into consideration certain aspects of their occupational background.

\section{Social Protest}

The established rural population of farmers (from whom the local authorities were largely recruited) excluded from their ranks the skinners and other marginal people, such as the entertainers and peddlers, as well as most of the spinners and weavers, many of the cobblers and saddlers, and other impoverished artisans-in short, what Turner (1974) described as "the structurally weak." It should therefore not surprise us that the Bokkerijders directed their operations against the principle symbols of this rural social order-namely, Roman Catholic churches, chapels, rectories, and tenant farms. The churches were not only plundered, but also often ritually attacked and subjected to various forms of ritual desecration. Here we move into the realm of the so-called "countertheater of the poor," which involves forms of popular protest that attack symbols of authority by means of parody, inversion, mockery, and other subversive comments (see Thompson 1974). Yet if the exclusion and stigmatization to which the skinners and many of their associates were subjected provided them with a cause, this leaves us with the question of why the bands took shape around 1730 and not before.

It is very likely that the skinners in this part of western Europe enjoyed a certain measure of prosperity in the decades around 1700 . Both the military operations that afflicted the area until the early eighteenth century, and the cattle plagues that struck various regions of the Continent during the second decade of that century, may have favored 
the skinning trade as much as they must have taken a toll from the farmers. After these scourges came to a temporary halt around 1720, the skinners must have entered a difficult period. There are indeed several indications for a notable decrease in employment for skinners in the 1720s and 1730s. We know that some of them had to insist on their local monopoly, others were continually in search of work, and still others had to move their business to other locations. Being skinners, they had few chances of finding employment outside their trade, so there were various appeals to their kinsmen. The wanderings of some of these skinners tell us something about the size of their regional network of kinsmen and affines. They also reveal that several of these artisans had lost their moorings and began to assume the characteristics of people living a vagrant life (Wilbertz 1979:154-159; Küther 1983:53-55). Contraction of employment, a recurrent phenomenon in postwar periods (see Beattie 1974), may also have forced some of the ironworkers to join the bands. Although impoverished, these craftsmen retained their sense of cohesion (predicated on their guildlike organization) as well as their mobility and their expertise with locks and keys.

One suspects that social resentment and class tensions, as well as poverty and unemployment, did much to inspire the operations of the Bokkerijders; most of the bands' outings involved a distinct element of hostility toward the established rural population, notably priests and wealthy tenant farmers. Especially during the first episodes, when the skinners and other artisans held in low esteem were prominent in the bands, victims were often severely beaten, regardless of their age and sex. Some were killed, or died soon after the attacks. As far as the plunderings of churches are concerned, the Bokkerijders did not restrict themselves to the theft of money and Mass vestments, chalices, and other cult attributes. During the 1730s, when churches seem to have become favorite targets, there were further desecrations in the form of parodies of the Mass. Following one successful looting of a church, a skinner distributed the holy Host on more than one occasion.

Elements of this popular countertheater were also conspicuous in the initiation ceremonies that accompanied incorporation into the bands. Apart from the robberies, which remained "family affairs" of sorts, larger operations in which more than a hundred people participated were carried out. With the expansion of the bands, recruitment and incorporation became formalized. New members had to swear an oath of allegiance and submit themselves to an initiation ritual in wayside chapels, the open air, and other liminal locations, or simply at the home of a 
local leader. In a sense, these ceremonies formed a continuation of the more spontaneous parodies of the Mass enacted by the skinners and took the form of inverted Roman Catholic liturgy. For instance, novices had to crawl on all fours into a chapel, sometimes going in and out backward. There were improvised altars with burning candles, holy statuettes, and images of the saints. The novitiates had to spit on a crucifix and throw it on the floor and step on it, while swearing off God and the Holy Mother and dedicating themselves to the devil.

It must have been these kinds of rituals of Teufelsbundner (confederates of the devil), as well as the remarkable mobility of the bands, that earned the robbers the name Bokkerijders (literally, billy goat riders). One does not find this denotation in the court records, although the judges acknowledged the existence of a sworn confederacy. The name was bestowed on the robbers by the local populace and had its roots in an ancient and widespread folk belief that associates the billy goat with the devil and his work, and with the notion of magical flight. As one of the local priests put it in 1779 , when the history of these bands had come to an end:

In many places, this band was given the name of Bokkeryers, that is to say, they rode on billy goats when they went out at night to steal. These billy goats would not have been natural billy goats, but the devil in the form of one or more billy goats. This devil would have carried them through the air in a short time to the place where they wanted to be, so that they were transported in a single night ten, sixteen, twenty hours away, to steal and to have their meeting; and they returned on the back of this billy goat. Some of the band have started to confess this and tried to make a hotchpotch of it. (Sleinada 1779:61-62)

Such meetings must have enhanced the cohesion of the robbers' network, ensured the secrecy of their conspiracy, reinforced their daring, and instilled in them a sense of belonging to a countersociety. These ceremonies appeared at a time when the bands started to grow rapidly and could not be tied together only by links of kinship, marriage, friendship, occupation, and locality, though such bonds continued to play an important role.

In the course of the 1750s and 1760s, the organization of the attacks was increasingly fashioned after military models. Although the number of ex-soldiers and people with military experience among the robbers was remarkably small (less than two dozen) and their share in leadership was equally limited, already from the beginning the operations of the 
bands bore a strong resemblance to the outings of looting soldiers (Gutmann 1980). From the mid-1750s on, when a local physician who had served as a recruitment officer in the Austrian army assumed leadership, the bands were organized on the model of a militia, with various divisions and subdivisions. At this stage, women had virtually disappeared from the bands. Thus an armylike organization was superimposed on a preexisting regional network of robbers that on the face of it was welded together for attacks on churches and farms. Actually, the large-scale operations seem to have served other goals.

Several clues suggest that the Bokkerijder bands had, in the third and final phase, developed into an abortive protest movement of sorts. This orientation of the bands is attested by several unsolicited statements of convicted band members. Some of them referred to what they called a "Brotherhood of Happiness." Others spoke of the impending foundation of a "New Kingdom" in which all property would be shared and "all of us have to be equal." Still others emphasized that once the bands had reached full strength they would steal, murder, and rob, killing all those who refused to join them. Moreover, several large-scale operations against farms, which took place shortly before the demise of the bands, were apparently highly unusual robberies. There were well over 200 participants, even though a dozen or so might have sufficed. Besides, the booty was often ridiculously small, and the victims were conspicuously spared. For all these reasons, one cannot but regard these outings as maneuvers of an incipient militia, aimed chiefly if not only at mobilizing large numbers of people from many different villages and towns in the Dutch and Austrian territories of the Lower Meuse. For most of the rank and file, these outings were disguised as ordinary attacks and robberies, for which they were modestly paid afterward. It is significant that the local leaders in this phase of the history of the Bokkerijder bands were primarily involved in recruiting new members for the bands, and we know that several of the candidates received handsel when they enlisted to join in a hitherto undisclosed expedition. As one convicted robber put it, "eventually taking everything from the Rich, and that everyone should do his utmost to recruit new members for the Band." Considering the available evidence, it looks as if the operations were there for the robbers, not the robbers for the operations. However this may be, the bands never made it into a real militia, let alone into a fullfledged political movement.

Paradoxically, the extreme fragmentation of political domains in the Lower Meuse did not prevent the authorities from coming to terms with 
the robber bands and eventually stamping them out altogether. Organized across the boundaries of various territories and jurisdictions, the bands could deceive and elude the bailiffs and their assistants for years. What triggered the series of trials against the Bokkerijders were not large-scale, regionally coordinated searches or hunts (which occasionally occurred with respect to roaming beggars and vagrants), but simply individual arrests of band members who had committed thefts on their own. Hard-pressed by the courts, these people began to talk, revealing the names of their accomplices, many of whom were consequently arrested and interrogated. In this way, court proceedings snowballed. It would be wrong to assume that the fragmentation of power domains inhibited cooperation between the authorities of different jurisdictions. Once the first arrests were made, courts began to exchange information about convicts, fugitives, and the whereabouts of other suspects. In addition, Bokkerijders who had fled were arrested in neighboring territories and, on request, extradited, as happened with some robbers who had tried to enlist in the regiments of the garrison towns of Düsseldorf, Maestricht, and Namur.

We now return to the actual theme of this chapter, the idiom of public executions in the Lower Meuse and a consideration of some aspects of the growing resistance against theatrical punishments at the end of the eighteenth century.

\section{The Theater of Punishments and Its Decline}

The sentences passed on the Bokkerijders in the early 1740s still showed all the characteristics of theatrical punishments with which people in most parts of early modern Europe had become familiar (see Foucault 1977; Schild 1980; Dülmen 1984; Blok 1984; Spierenburg 1984). The executions were not only public, carried out in or near the home towns of the convicts, but also true spectacles, intended for an audience that included kinsmen, friends, neighbors, and other fellow townsmen of the condemned. The crowd knew the person who was being put to death, and, as we shall see, the actual punishment often conveyed the nature of the crime.

Invariably situated at the limits of the jurisdictions, the place of execution was a clearly demarcated location, usually an elevation or hill (hence the denotations galgeheuvel and galgeberg [gallows hill], which still survive as toponyms). Thus the condemned had to be escorted all 
the way from the place of detention to the liminal location. Such processions were very much a part of the theater of punishments. The condemned were on exhibition, which reinforced their humiliation and infamy even more. A local man who had witnessed public hangings even into the late eighteenth century recalled during an interview in 1848:

The place of execution of our territories was usually located on the border of the commune. The gallows of the village of Oirsbeek, for example, were situated at the other side of Amstenrade, at Treebeek, on the border of the commune of Heerlen. Those who were condemned to be whipped, branded, or broken on the wheel were put on a cart and transported to this location. The constable led the way. As a sign that a sentence had been passed, he carried the red-painted rod of justice: a prickled stick of about 90 centimeters long with golden acorns as garlands. After him in the parade came the bailiff with the alderman. The militiamen from the parish of the condemned surrounded the cart. They were armed with rifles and had cockfeathers on their hats. The banner and drum were covered with mourning crepe, and the drummer beat a funeral march. As the procession arrived at the place of execution, the militia gathered around the gallows to keep the crowd at a distance. Then the bailiff read out the sentence, whereupon the condemned mounted the ladder. When the bailiff took the rod of justice and let it sink, the hangman's rope fell. (Habets 1889:25)

For many Bokkerijders condemned in the early 1740s, such processions constituted only the preliminaries of their ordeals. While out of a total of well over one hundred convicts about fifty were hanged in chains, "until their remains fell off," more than forty robbers were subjected to further tribulations before they expired or were finally put to death (see Table 1.2). Each of these afflictions conveyed something about the crimes they had committed. Foucault rightly observed that the body of the condemned man formed an essential element in the ceremonial of public executions: "It was the task of the guilty man to bear openly his condemnation and the truth of the crime that he had committed. His bodydisplayed, exhibited in procession, tortured-served as the public support of a procedure that had hitherto remained in the shade; in him, on him, the sentence had to be legible for all" (1977:43). The main elements of this code included three forms of punishments: the gallows, the wheel, and fire. Ordinary thieves were whipped and banished; those who had committed qualified thefts were hanged; murderers and bandit leaders were broken on the wheel; and arson and sacrilege (e.g., church robberies) were punished by various forms of burning. Because the 
Bokkerijders had indulged in all these felonies, and because the local courts of the villages and towns in the eastern Meuse valley seemed to have seriously tried to reenact these crimes, at least initially, the sentences passed on the robbers provide us with several examples of the "theatrical reproduction" of delicts in executions.

The symbolic vocabulary included the case of one man who, before he was hanged, had his face blackened and two fingers of his right hand cut off. A German pamphlet published in 1744 reported:

\section{Dabey auch (wie Viel im Leben) \\ Wurd geschwärzt ihr Angesicht, Um das auch an Tag zu geben, Eh' sie wurden hingericht.}

Man thät die zwei Finger brennen Dessen der geschworen hat, Nur den Teufel zu erkennen, Wurd gestraft auch zu Neustadt.
Thereby also (as many had been when alive)

Were blackened their faces,

To make this also known,

Before they were executed.

One burned the two fingers

Of those who had sworn,

To recognize only the devil,

They were punished also in Nieuwstadt.

Because many robbers had also broken into churches and committed various profanities, their execution included several combinations of capital punishments as well as various forms of burning at the stake. No less than twenty Bokkerijders were garroted and then burned. At least one robber was executed the same way, after having his right hand first smeared with sulfur, then burned, and finally chopped off. Several others, who had held leading positions in the bands, were broken on the wheel and decapitated, after having the right hand burned and chopped off; their bodies, together with the severed limbs, were displayed on the wheel, and their heads were put on iron pins.

Some of these executions assumed the character of true spiegelstraffen (literally, mirror punishments) - that is, the executions, or certain stages of them, were meant to reflect exactly the nature of the crimes the condemned had committed. This was the case, for example, with the robbers who had blackened their faces while breaking into houses and farms. Similar literal reenactments of the delicts were included in the execution of two skinners. One of them had, among other things, murdered a traveler with his stick and killed an innkeeper with his knife. Before he was broken on the wheel and burned, he received a stab with a knife in his side and four blows with the stick on his head. His brother, who had misled the judges, had his tongue sliced off before he was burned at the stake. Another robber had his right hand burned and cut 
off; their bodies, together with the severed limbs, were displayed on the fur on the limbs of one of his victims and set fire to it in order to make her disclose the location of her money and other valuables. But this specific punishment was also applied to those who had broken into churches.

A theatrical element-again emphasizing the infamy of the condemned and his family - was not lacking in some of the additional punishments. We know of some cases in which the house of the convict had to be demolished with the stipulation that no building was to be erected on the site for the next hundred years. Theatrical dimensions werealso obvious in the punishments of virtually all forty-six people who had died in detention. Like elsewhere, convicts who had died in prison were also tried, or rather a sentence was passed on their remains. In only four cases were the bodies, upon request, returned to kinsmen and then buried in the churchyard or elsewhere, "in unconsecrated earth." Usually, however, the local skinner took charge of the bodies, dragging them on a sledge all the way to the gallows at the border of the jurisdiction, where he either buried or hanged them in chains, depending on the degree of decomposition. The bodies of those who had committed suicide were usually hanged from the gallows by one leg. Two of the suicides had their faces blackened for the same reason as their associates mentioned above. But why were suicides hanged by one leg? Perhaps it was an attempt to express, by a symbolic inversion in a mirror punishment, the unusual and criminal character of suicide committed by someone who was already exceptional and criminal. Leach observed on the logic of such reversals:

In days when the monarchy was a locus of greater power than is now the case, those who had caused the King offence were punished first by being incarcerated in dungeons below ground and then by being hung on gibbets with their bodies suspended above the heads of passers-by. The inner logic of such customs includes such reversals as the following: if living Kings are "above" normal commoners, they are still more above criminals. But if dead Kings are buried below us in the ground, then dead criminals should be suspended above us in the air. Such arguments do not explain why offenders were alternately imprisoned below ground in dungeons and then suspended above ground on gibbets, but they do show that such apparently contrasted customs are mutually consistent. (1972:336)

What also underscores the importance of the theatrical element in the punishments under the ancien régime was the fate of those who were flogged and banished. Some of them were put on the scaffold with the 
hangman's rope around their neck, indicating that their next offense would be punished by death. Thus exhibited, they were whipped, receiving a fixed number of blows with a fixed number of birches, whereupon they were banished from the district. The element of spectacle could be as strong in some of the sentences passed on those who were tried in absentia. Although most of them seemed to have simply been banished, we know of at least eleven Bokkerijders who were hanged in effigy. Also in these cases, the "executions" took place on the usual location in the home towns of the condemned.

As specified in the sentences pronounced by the local courts, the main function of these public executions was "to inspire fear and to set an example." Although the recruiting areas of the robbers shifted somewhat over the years, one cannot say that the mass executions did much to discourage brigandage in these territories of the Lower Meuse, let alone stamp it out altogether. The bands reemerged on two occasions in more or less the same districts, with increasing enthusiasm and growing numbers. First, in 1749-after a brief interval during which the movement of troops in the last phase of the Austrian War of Succession precluded any brigandage in the area-Bokkerijder activity assumed the form of a short "entr'act" in which one encounters familiar faces next to new ones. Later, in the 1750s and 1760s, the bands operated on a larger scale and became much larger, including several hundred participants, many of them from Dutch territories. More than once the robbers carried out attacks in places not far from where the trials and executions of their confederates were in full swing. Yet a third reemergence did not take off, probably because of the radical political changes taking place at the end of the eighteenth century, when the French occupied the Low Countries and the Rhineland and introduced a more centralized system of administration. On the other hand, organized brigandage may also have exhausted itself in the Lower Meuse before political integration took place.

Considering all the sentences pronounced and carried out during the second and third phases of trials - that is, during the early $1750 \mathrm{~s}$ and throughout the 1770s-and comparing them with the baroque punishments of the early 1740s, one cannot fail to notice an overall attenuation of the supplices (torture). First, the element of fire was conspicuously absent from the theater of punishment, and the combination of elements of various capital punishments in one and the same execution did not occur either. Second, most of the death sentences passed in the $1750 \mathrm{~s}$ and 1770s involved simply hanging; of 262 convicts, 254 were sent to the gallows, while hanging occurred in only about half the death sentences 
carried out in the early 1740s (see Table 1.2). Distinctly theatrical elements were present in relatively few cases: in the execution of six band leaders who were broken on the wheel; in nine cases of convicts who were flogged and banished; in ten cases of robbers who were tried in absentia and hanged in effigy; and in thirty cases of convicts who had died in prison and whose bodies were dragged to the gallows by the local skinner. Finally, at least sixty Bokkerijders were tried in absentia and simply banished from these territories. Thus, compared with the sentences pronounced in the 1740 s, the symbolic vocabulary of these late eighteenth-century punishments had lost much of its eloquence. It is perhaps revealing that the long series of verdicts passed in the $1770 \mathrm{~s}$ started with two cases of garroting, a sentence never to be repeated. The last sentences pronounced in this phase included three cases of confinement, a number of banishments, and several cases of suspects released from detention.

The attenuation of corporal punishments in the Lower Meuse fitted a more general European pattern. It was part of the gradual, long-term transition from corporal punishment to confinement (Foucault 1977; Langbein 1977; Spierenburg 1984). This is also attested by the views and proposals of a government official in one of the Dutch territories in the eastern Meuse valley, Louis Adriaan Pélerin, who was appointed luitenant-voogd (vice-governor) of Valkenburg at the end of 1775 when the trials against the Bokkerijders were already drawing to a close. Pélerin showed specific concern with the way the local courts proceeded against the robbers. In his letters to the Estates General in The Hague, he argued compassionately and persuasively for moderation of the penalties to be imposed on the still surviving members of the bands, especially the rank and file. Shocked by the mass executions as well as by the use of torture to obtain confessions, which he described as "horrible," "barbarous," and "in conflict with humanity," Pélerin pointed out that torture had already been abolished in several neighboring countries and that executions on such a large scale risked missing the point of corporal punishment in public - that is, to inspire fear and to set an example. He mentioned that indeed the massive executions in the 1770s had caused serious trouble among the local population and that the authorities had to call on the garrison in Maestricht to prevent the outbreak of disorder during the executions.

Rather than punishing people for crimes already committed, Pélerin, like other enlightened jurists in late eighteenth-century Europe, advocated putting the emphasis on prevention of crime. His plea for the 
establishment of workhouses and the abolition of kermesses and other popular festivals (of which there were many in the area), and his suggestion to restrict the distribution of alcohol and the number of inns and taverns, was based on the assumption that one could prevent crime by controlling the populace. His proposal to improve police regulations and to introduce a marechaussée (constabulary) of sorts served the same goal. The Estates General reacted favorably to these proposals, most of which were consequently carried out (Habets 1887).

The concerns involved in these reforms were not only humanitarian. In the emphasis on restraints and confinement, one can discern a growing preoccupation of the enlightened elite with the classes dangereuses, whose ranks had started to grow dramatically from the mid-eighteenth century on (see Chevalier 1978). Moral and pragmatic considerations were indeed closely intertwined. We are dealing, on the one hand, with a growing sensitivity regarding the use of violence and all kinds of "disorder"-including various manifestations of popular culture, such as dissolute behavior at kermesses and in taverns - and, on the other hand, with the recognition that both judicial torture and theatrical punishments had run their course and were becoming counterproductive. The authorities realized that one could control crime in both a more "civilized" and more effective way by improving and extending controls over the population. In fact, with the political integration of various territories and the formation of modern bureaucratic states, central control over larger populations became more stable and effective. And it was precisely in such states as Prussia and Austria that judicial torture was first abolished and that death sentences were often substituted by extraordinary punishments involving various forms of confinement (Langbein 1977). Apart from a growing sensitivity, this may help explain why the reforms proposed by Pélerin were favorably received by his superiors in The Hague. It may also explain why the Bokkerijder bands did not reemerge in the Lower Meuse for a third time.

\section{REFERENCES}

Beattie, J. M. 1974. "The Pattern of Crime in England, 1660-1800." Past and Present 62:47-95.

Blok, Anton. 1979. "Wie waren de Bokkerijders?" Tijdschrift voor Sociale Geschiedenis 5(2):168-200.

_ 1981a. "De rol van vilders in de Bokkerijdersbenden." Volkskundig Bulletin 7(2):121-142.

- 1981b. "Infame beroepen." Symposion 3(1-2):104-128. 
1984. “Openbare strafvoltrekkingen als rites de passage." Tijdschrift voor Geschiedenis 97(3):470-481.

Chevalier, Louis. 1978. Classes laborieuses et classes dangereuses à Paris, pendant la première moitié du 19 e siècle. $2 \mathrm{~d}$ ed. Paris.

Dülmen, Richard van. 1984. "Das Schauspiel des Todes." In Richard van Dülmen and Norbert Schindler, eds., Volkskultur. Zur Wiederentdeckung des vergessenen Alltag (16.-20. Jahrhundert), pp. 203-245. Frankfurt am Main.

Foucault, Michel. 1977. Discipline and Punish: The Birth of the Prison. Trans. Alan Sheridan. Harmondsworth, Eng.

Gierlichs, W. 1972. De geschiedenis der Bokkerijders in 't voormalig land van 'sHertogenrode. $2 \mathrm{~d}$ ed. Maastricht.

Gutmann, Myron P. 1980. War and Rural Life in the Early Modern Low Countries. Assen.

Haas, J. A. K. 1978. De verdeling van de Landen van Overmaas, 1644-1662. Territoriale desintegratie in een betwist grensgebied. Assen.

Habets, J., ed. 1887. “Ambtelijke brieven en andere bescheiden over de Bokkerijders in het Staatsch Land van Overmaas, 1775-1782." Publications 24:1-113.

- 1889. "Een Valkenburgsch dorp in 1789." Publications 26:3-28.

Hobsbawm, E. J., and Joan Wallach Scott. 1980. "Political Shoemakers." Past and Present 89:86-114.

Küther, Carsten. 1983. Menschen auf der Strasse. Vagierende Unterschichten in Bayern, Franken und Schwaben in der zweiten Halfte des 18. Jahrhunderts. Göttingen.

Langbein, John H. 1977. Torture and the Law of Proof: Europe and England in the Ancien Regime. Chicago.

Leach, Edmund. 1972. "The Influence of Cultural Context on Non-verbal Communication in Man." In R. A. Hinde, ed., Non-verbal Communication, pp. 315347. Cambridge.

Philips, J. F. R. 1975. “Enige aanduidingen omtrent de bevolkingsontwikkeling van de $17 \mathrm{e}$ tot het einde van de $18 \mathrm{e}$ eeuw in het gebied van de huidige provincie Nederlands Limburg." Jaarboek van het Sociaal-Historisch Centrum voor Limburg 20:1-47.

Roebroeck, E. 1967. Het Land van Montfort. Een agrarische samenleving in een grensgebied, 1647-1820. Assen.

Schild, Wolfgang. 1980. Alte Gerichtsbarkeit. Vom Gottesurteil bis zum Beginn der modernen Rechtsprechung. Munich.

Schrijnemakers, M. J. H. A. 1984. Rode. De oudste nederzettingsgeschiedenis van het Land van Rode. Maastricht.

Sleinada, S. J. P. 1779. Oorsprong, oorzaeke, bewys en ondekkinge van een godlooze bezwoorne bende nagtdieven en knevelaers binnen de Landen van Overmaeze en aenpaelende landtstreeken ontdekt, etc. Reprinted in Maastricht in 1972.

Slicher van Bath, B. H. 1963. The Agrarian History of Western Europe, A.D. 5001850. Trans. Olive Ordish. London.

Spierenburg, Pieter. 1984. The Spectacle of Suffering: Executions and the Evolution of Repression: From a Preindustrial Metropolis to the European Experience. Cambridge. 


\section{Anton Blok}

Thompson, E. P. 1974. "Patrician Society, Plebeian Culture." Journal of Science History 7(4):382-405.

Thurlings, T. L. M., and A. A. P. van Drunen. 1960. "Sociaal-economische geschiedenis." Limburgs Verleden 1:191-247.

Turner, Victor. 1974. Dramas, Fields, and Metaphors: Symbolic Action in Human Society. London.

Wilbertz, Gisela. 1979. Scharfrichter und Abdecker im Hochstift Osnabrück. Untersuchungen zur sozialgeschichte zweier "unehrlicher" Berufe im nordwesdeutschen Raum von 16. bis zum 19. Jahrhundert. Osnabrück.

Wouters, H. H. E. 1970. Grensland en bruggehoofd. Historische studies met betrekking tot het Limburgse Maasdal en, meer in het bijzonder, de stad Maastricht. Assen. 